\title{
US and biologists wary of strict biotech rules
}

\section{David Cyranoski, Kuala Lumpur}

How best to judge the potential environmental danger of a genetically modified organism? That's the question that dominated the first meeting of the parties of the Cartagena Protocol on Biosafety in Kuala Lumpur, Malaysia, last week. Attendees eventually agreed that detailed biological information should be provided with each shipment of genetically modified grain.

The outcome disappointed representatives of the largest exporters of genetically modified crops, notably the United States. Plant researchers were also worried that the proposed rules might reduce the sharing of materials.

It remains unclear whether tighter rules will slow the march of agricultural biotechnology, however - or simply render the protocol itself irrelevant. The United States and its allies are pursuing free trade in the technology through the World Trade Organization. If they succeed, observers say, it could render the biosafety protocol moot.

The protocol, provided for under the United Nations' 1992 Convention on Biological Diversity and enacted on 11 September 2003, aims to ensure the safe international shipment of what it calls living modified organisms. The meeting, which ran on 23-27 February, was the first attempt to decide how to implement this.

Delegates argued into the early hours of 27 February on how to enforce the protocol and how to manage compensation when damage occurs. The protocol is legally binding on the 87 countries that have ratified it.

The sharpest point of contention was the protocol's guidelines for labelling shipments of genetically modified organisms. The United States and its allies want to minimize additions to the existing rule for package markings to state that they "may contain"

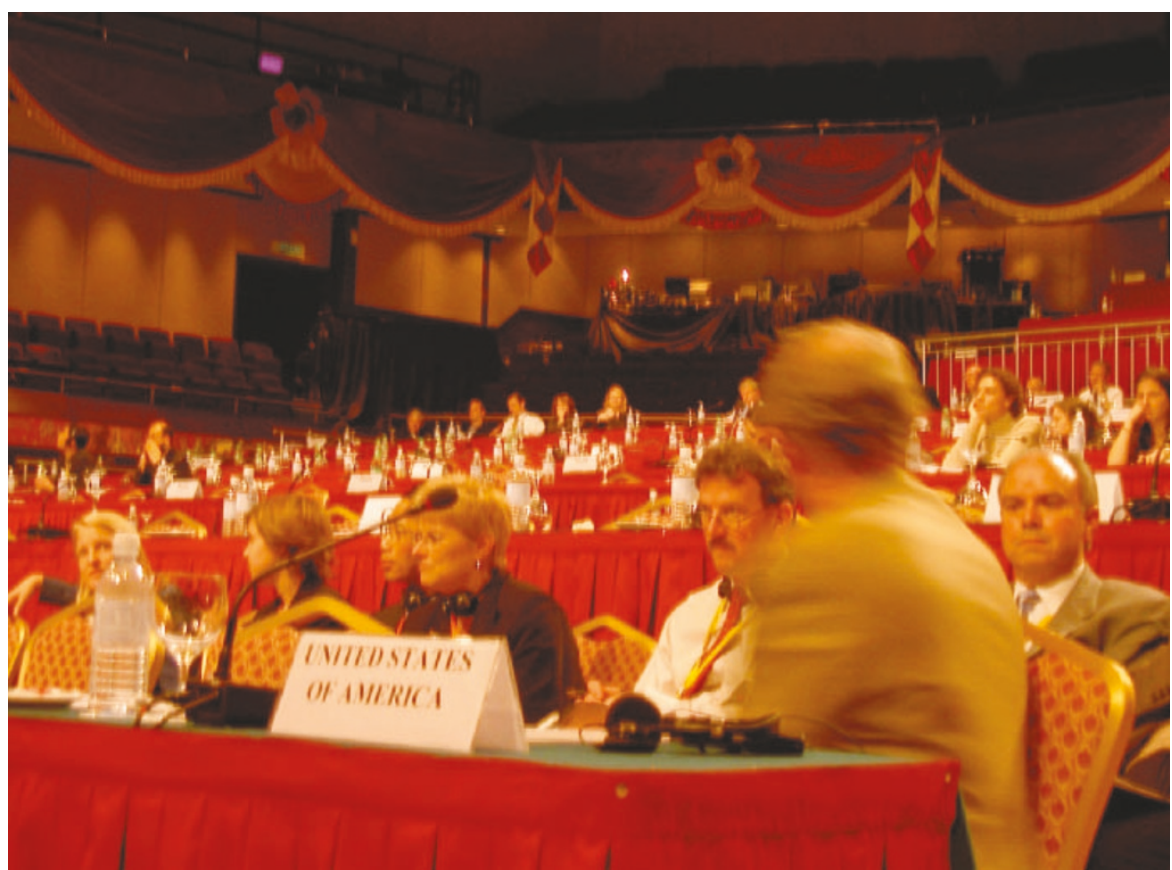

Cold shoulder? US observers found little to smile about at the first biosafety summit.

such organisms. The United States, which isn't party to the protocol, but has been trying to observe it in practice, agreed with Canada and Mexico last October that exporters need not expand on this.

Anything more specific would hinder shipping, US representatives argued. "There are 12 or so varieties of genetically modified maize in commercial use - we have no idea what's in most shipments," says John Pitchford, who works in the US Department of Agriculture's office of international affairs.

But in Kuala Lumpur, representatives of the European Union and African nations successfully argued that exporters should put common and scientific names on each shipment, and information on the genetic

\section{Gene-ecology agreement circles the globe}

Thirty hours of flight time separate Troms $ø$ in Norway and Christchurch in New Zealand. But researchers in the two cities have unearthed a common interest - gene flow - that springs from their respective positions as gateways to pristine polar regions. And last week, at the first meeting of parties to the biosafety protocol (see above), they agreed to team up to help other nations assess the risks of genetically modified organisms.

The Norwegian Institute of Gene Ecology (GenØk), based at the University of Tromsø, and the New Zealand Institute of Gene Ecology at the University of Canterbury in Christchurch, signed an agreement with the United Nations Environment Programme to help poor countries build the infrastructure needed to test genetically standards.

The two institutes have pioneered the new and contentious field of gene ecology, a discipline that includes the study of how consumption of transgenic foods affects the genes and long-term health of animals. "We start out by looking for differences where other groups assume everything will be the same," says Terje Traavik, scientific director of GenØk. The subdiscipline combines genetics, biochemistry, ecology and social analysis of related issues, he says.

The collaborators have received 5 million kroner $(U S \$ 700,000)$ for the project's first year from the Norwegian government, and hope this will be renewed annually. modified organisms against environmental safety transformation event used to make each variety. Advocates say developing countries need this information for their own risk assessments. "We need to be able to check for ourselves," says David Hafashimana, a conservation biologist at Uganda's Ministry of Water, Lands and Environment.

Parties to the protocol will now begin implementing this approach, although the details won't be decided until another meeting in Germany later this year.

The few scientists among more than 1,000 negotiators and observers at the meeting expressed concern that the agreement will complicate the already fraught issue of sharing transgenic materials with colleagues abroad (see Nature 420, 602-604; 2002).

The agreement specifies that a significant amount of information, such as the transformation event and risk class, should be provided with all samples shipped for research. Hafashimana says that importing countries need this information: "In the case of an accident, how can we take appropriate measures if we don't know what it is?"

But Taesan Kim, a plant geneticist at the National Institute of Agricultural Biotechnology in Suwon, South Korea, is concerned that 'transformation event' could mean the number of insertions in a genome, the site of insertion, or even precise DNA sequences. "That's a lot of data," he points out.

And Kazuo Watanabe, a plant researcher at the University of Tsukuba near Tokyo, worries that cell cultures could attenuate while waiting in customs offices. "Researchers might become reluctant to send materials," he warns. 